Błażej Cecota (Łódź)

\title{
Islam, The Arabs and Umayyad Rulers ACCORDING TO THEOPHANES THE CONFESSOR's Chronography
}

The Chronicle of Theophanes is, as it has been known for decades, a very important source not only for the history of the Byzantine Empire, as it also includes a lot of information about the foreign states and tribes which were connected with it ${ }^{1}$. In this article I will try to analyse the account concerning Islam and the Arabs by this Byzantine author (bearing in mind the still discussed problem of authorship, and above all, the matter of his oriental source[s], on which he relied and which he cited ${ }^{2}$ ). The chronicler's view on Islam itself has been discussed at length by the modern scholars ${ }^{3}$, yet his attitude towards Arabs and Umayyad rulers seems equally noteworthy, even if sometimes sketchy, varied or indistinct. Therefore, I am going to make both these questions the primary subject of my considerations.

\footnotetext{
1 The bibliography on the subject of Theophanes and his work is enormous. The following papers should be listed here: A.S. Proudfoot, The Sources of Theophanes for the Heraclian Dynasty, B 44, 1974, p. 367-439; С. MANGo, Who wrote the Chronicle of Theophanes?, ЗРВИ 18, 1978, p. 9-17; L.M. Wнітву, The Great Chronographer and Theophanes, BMGS 8, 1982/1983, p. 1-20; O. JUREwICZ, Historia literatury bizantyńskiej. Zarys, Wrocław 1984, p. 132-137; J.N. LJUBARSKIJ, Concerning the Literary Technique of Theophanes the Confessor, Bsl 56, 1995, p. 317-322; C. MAngo, Introduction, [in:] The Chronicle of Theophanes Confessor. Byzantine and Near Eastern History AD 284-813, trans. IDEM, R. SCOTT, with assistance of G. Greatrex, Oxford 1997, p. XLIII-C; A.P. Kazhdan, a History of Byzantine Literature (650-850), Athens 1999, p. 205-234.

2 This issue of the oriental source and parallel historiographic traditions has been recently tackled by R.G. Hoy Land in Theophilus of Edessa's Chronicle and the Circulation of Historical Knowledge in Late Antiquity and Early Islam, trans. et ed. IDEM, Liverpool 2011, p. 7-10, 19-29, 310-315 and passim; different approach was presented during the international symposium The Chronicle of Theophanes: sources, composition and transmission (Paris, $14^{\text {th }}-15^{\text {th }}$ September 2012) by M. Conterno, Theophilos, "the more likely candidate"? Towards a reappraisal of the question of Theophanes' "Oriental Source(s)", and M. Debié, Théophile d'Edesse, le fantôme de l'historiographie syriaque (both texts will be published in 2013).

3 On this subject vide e.g. J. MeyendorfF, Byzantine Views of Islam, DOP 18, 1964, p. 113-132; D.J. SAHAs, Eighth-Century Byzantine Anti-Islamic Literature: Context and Forces, Bsl 57, 1996, p. 229-238.
} 


\section{Muhammad and Islam}

In his chronicle Theophanes included a lot of information regarding $\mathrm{Mu}$ hammad. The knowledge which the former had of the latter can be considered to be precise, which seems to reflect relative completeness of his source material. Still, bearing in mind that the chronographer did not obviously have a direct steady contact with the Arabs, the accuracy of the information he conveyed can be to some extent surprising. This fact led some researchers to formulate the thesis that Theophanes acquired a fundamental knowledge of the subject from the translations of Muslim literature, for instance Sirat by Ibn Hisham ${ }^{4}$. However, this idea may be a bit controversial and hard to agree with ${ }^{5}$, as it is known that the author lived 150 years after Muhammad's death, in a country which had stable, sometimes harmonious and sometimes warring, relationships with the caliphate. Therefore, it was impossible that information about the prophet did not reach the empire (if one recalls of the Palestinian group in Constantinople and the fate of George Syncellus's fate, the issue gains one more probable explanation and convenient line of the Byzantine transmission). This information may seem to be so detailed because of the fact that Theophanes tried to present an exclusive, cohesive story of Muhammad's life. He focused on certain details, not mentioned by any other chroniclers, either Byzantine or others from the countries under Arab occupation.

The Byzantine writer mentioned that Muhammad lived being destitute and an orphan ${ }^{6}$. Thus, he must have had the information about his father's death and the difficult childhood of the future Muslim leader ${ }^{7}$. Similarly, he also noticed the meaningful role of the prophet's wife - Khadija bint Khuwaylid - his main spokesperson in the first period of his mission. It is consistent with the Muslim tradition ${ }^{8}$. Theophanes also underlined Muhammad's profession trade allowed him to have frequent contact with the Jews and the Christians. The chronographer suggested that the future prophet wished to have this connection. According to his account

4 Ю. Максимов, Прп. Феобан Исповедник Сигрианский об истаме, 2003, http://www.pravoslavie.ru/ put/apologetika/feofanispovednik-islam.htm [12 VII 2012].

5 First of all for chronological reasons. Probably Ibn Hisham was younger than Theophanes (he died in 828 or 833 ).

6 Theophanis Chronographia, AM 6122, rec. C. DE Boor, vol. I, Lipsiae 1883 (cetera: Theophanes), p. 333, 22-23. English quotations from: The Chronicle of Theophanes Confessor... Syriac accounts on $\mathrm{Mu}-$ hammad are collated with Theophanes in R.G. Hoyland, op. cit., p. 86-92.

7 The literature on the subject of Muhammad's childhood is abundant, here just a few examples: M. Gaudefroy-Demombynes, Mahomet, Paris 1969, p. 43-49; M. Rodinson, Mahomet, Paris 1968, p. 42-70; B. Rogerson, The Prophet Muhammad. a Biography, London 2003, p. 54-75.

8 More information on the subject of Khadija's image, which is often ambiguous, can be found in Muslim sources, vide M. Dziekan, Hadiga, żona Proroka Muhammada w Usd al-gaba fi ma 'rifat as-sahaba 'Izz ad-Dina al-Atira i innych klasycznych źródłach arabskich, [in:] Kobiety Bliskiego Wschodu, ed. IDEM, I. KoŃCZAK, Łódź 2005, p. 11-23. 
Muhammad was even searching for books where the dogmas of both religions would be explained'.

Despite this detailed information, Theophanes did not seem to forget about the main purpose of his account, which was to present the doctrine of Islam as false. Therefore, one cannot agree with the statement that the chronographer (or his sources) tried to describe the Muslim religion in an objective way ${ }^{10}$. There are three passages of his work which specifically prove this point. The first one refers to the Jews and their reaction to Muhammad's teaching. Theophanes used an interesting method here - according to him, the Jews seem to be doubly doubtful about Islam. At first they were to accept this doctrine, which for a Christian would be an important argument against its authenticity ${ }^{11}$. Later they rejected this religion as false. The picture presented by Theophanes appears to suggest that Islam is so mendacious that even the Jews, blasphemers themselves, refused it ${ }^{12}$.

The aforementioned observation is also confirmed by the information about Muhammad's epilepsy ${ }^{13}$. Theophanes, as the first among the Christians, stressed that the prophet suffered from this health problem. According to him, Muhammad may have been trying to hide this illness claiming that his strange behaviour was caused by prophetic visions ${ }^{14}$. It is worth emphasizing that, according to the chronicler, an anonymous monk who had been exiled for his depraved doctrine played the main role in confirming this version of events ${ }^{15}$. It might have been Waraqa Ibn Naufal, Khadija's cousin ${ }^{16}$.

\footnotetext{
9 Theophanes, AM 6122, p. 334, 3-4.

10 Ю. МАКСИМов, op. cit.

11 Theophanes, AM 6122, p. 333, 4-9.

12 Theophanes, AM 6122, p. 333, 9-11.

13 The Byzantines knew the works of Galen, in which epilepsy was regarded as a natural disease. Michael Psellos' works can serve as good examples here. However, the most common reason for epilepsy was believed to be evil powers and demons. Such beliefs were mainly spread by the works of the Church Fathers, in which they adduced the fragment of the Synoptic Gospels referring to the healing of an epileptic boy by Jesus. This fragment tells the story of an evil spirit which possessed the boy. It is interesting that the motif of epilepsy sometimes was used in order to depreciate someone or their decisions. It happened that even some emperors were described in this fashion because being possessed by a bad spirit could mean that the ruler was deprived of God's protection, which was one of the basic attributes of his power. Therefore, his actions and decisions did not have the same importance as ones of a fully healthy person. More on this subject vide L.I. ConRAD, Zeno, the Epileptic Emperor: Historiography and Polemics as Source of Realia, BMGS 24, 2000, p. 61-81.

14 Theophanes, AM 6122, p. 334, 5-10.

15 Theophanes, AM 6122, p. 334, 10-14.

${ }^{16}$ A few Christians lived in Mecca and Medina. However, they were exceptions and they did not probably form organized communities in these cities. Numerous people converted to Christianity in the regions of Syria. Some of them, e.g. 'Usman Ibn al-Huwayris and Abu 'Amir al-Rahib, were accused of collaborating with the Byzantines. According to the Muslim sources, he was said to ask Heraclius himself for help, since he did not want the same changes that Muhammad had made in Medina for fear that it would threaten the freedom of his worship. More on this subject cf. G. Osman,
} 
Theophanes underlined that Islam was first adopted by women and only later, through their advocacy, men started to convert to this religion ${ }^{17}$. Such a passage could have been aimed at depreciating the Muslim faith even more.

One may wonder if Theophanes used Muslim sources while writing this passage $^{18}$. If this was the case, the story of Muhammad's life would be a very interesting example of how to make a pamphlet out of a panegyric (because such was the tone of the Muslim accounts). The reader cannot resist the impression that Theophanes' chronicle served as a tool of propaganda. However, its educational value should not be underestimated. This passage could also have been a kind of a manual for all the Byzantines that gave instructions how to communicate with the Muslims, which was useful in discussions. Theophanes might have expected that if a Muslim started a discussion about the prophet, it would be based on Sirat by Ibn Hisham. What is more, Yurij Maximov suggests that the chronicler described the figure of Muhammad in so much detail because he knew that in the main Christian texts by John Damascene, arguing with Islam, this matter was not developed enough ${ }^{19}$. Therefore, Theophanes did not cover the doctrine of the Muslim religion, deeply analyzed by John, so extensively; the character of the genre seemed to contribute as well.

One can get the impression that the author of Chronography mentioned only these dogmas of Islam which could be the most repulsive for the Christians. First of all, he emphasized the faith in an eternal reward for participating in a war ${ }^{20}$. Moreover, the chronographer concluded indirectly that Islam succeeded, in fact, only thanks to wars ${ }^{21}$.

Another issue that Theophanes described in his account was the Muslim concept of Paradise. Theophanes deprecated the belivers of Islam saying that the only things that mattered for them as a reward for a pious life were sensual and earthly pleasures. Amongst others, he enumerated intemperance in eating and drinking and the relationships with women, who were exchanged at will and treated like objects $^{22}$. In conclusion, the Byzantine author expressed the view that a Christian should simply sympathize with the people being so mistaken ${ }^{23}$.

Pre-Islamic Arab Conquest to Christianity in Mecca and Medina: An Investigation into the Arabic Sources, MWo 95, 2005, p. 67-80.

17 Theophanes, AM 6122, p. 334, 14-17.

18 The majority of researchers agree that Theophanes used Syrian sources, obviously translated into Greek. We cannot be sure, however, about the identity of the primary source. It appears that it has not survived until the present times - I. Rochow, Byzanz im 8. Jahrhundert in der Sicht des Theophanes. Quellenkritisch-historischer Kommentar zu den Jahren 715-813, Berlin 1991, p. 46-48; C. MANGo, Introduction..., p. lxxxii-lxxxvii.

19 Ю. МАКСимов, op. cit.

20 Theophanes, AM 6122, p. 334, 20-22.

21 Theophanes, AM 6122, p. 334, 17-19.

22 Theophanes, AM 6122, p. 334, 22-24.

23 Theophanes, AM 6122, p. 334, 26-27. 
It is worth emphasizing that the information presented above is included in one coherent passage in the Chronography. However, in a further part of this work one may discover a lot of information regarding Muslim behaviour. We can also learn from it a lot about what Theophanes or his milieu thought about the Arabs and their rulers - the caliphs. First of all, the author will tackle the accounts regarding the Arabs themselves.

\section{The Arabs}

Firstly, Theophanes noticed that the Muslims did not consist of homogeneous groups, and he was aware that they were divided according to their social background or political and religious preferences. It is worth noticing that the chronographer had very detailed knowledge concerning the different unrests and political riots in the caliphate, even those that began in distant regions of Persia. He described in detail both the civil war in the 80 s of the $7^{\text {th }}$ century ${ }^{24}$ and seizing the power by Marwan $\mathrm{II}^{25}$. He also pointed out numerous unorthodox religious movements, which were born in the same time ${ }^{26}$. It is a very interesting observation, because Islam and the Muslims have been often presented as a monolith. Theophanes, aptly making use of his source(s), noticed the differences and wrote about them openly.

This fact did not disturb him, in many places of his Chronography, to use unflattering words to depict the Muslims or the Arabs, who were treated as whole. First of all, the author often showed the Muslim believers as the enemies of God. It is especially visible in the descriptions of the sieges of Constantinople when Theophanes used this term a few times ${ }^{27}$. In this context, it is very significant that Theophanes attributed the victories in these battles directly to $\mathrm{God}^{28}$. It seems that the Byzantines treated these wars

${ }^{24}$ The fragments concerning this conflict can be found in the following passages: Theophanes, AM 6175, p. 360, 27-361, 3; AM 6178, p. 363, 21-32; AM 6180, p. 364, 19-23; AM 6181, p. 364, 29-365, 3 .

25 Theophanes, AM 6235, p. 418, 14-419, 6.

${ }^{26}$ One example is the description of the origins of the Kharijite sect. To find more information on Kharijites and other sects which came into existence in the early Islamic period, cf. G. Levi DeLLA VIDA, Kharidjites, [in:] Encyclopedia of Islam, vol. IV, Leiden 1978, p. 1074-1077; P. CRONE, Ninth-century Muslim anarchists, PP 167, 2000, p. 3-28; EADEM, The Kharijites and the caliphal title, [in:] Studies in Islamic and Middle Eastern Texts and Traditions: in memory of Norman Calder, ed. G. Hawting, J.A. MojAdDEdi, A. Samely, Oxford 2000, p. 85-91; J. Danecki, Podstawowe wiadomości o islamie, vol. I, Warszawa 2002, p. 165-189; A. GAISER, What do we learn about the early Kharijites and Ibadiyya from their coins?, JAOS 130, 2010, p. 167-187; R.G. HoYLAND, op. cit, p. 149, an. 375.

${ }^{27}$ It should be highlighted that the author calls them explicitly 'fighting against God' [oi $\theta \varepsilon o \mu \alpha \dot{\alpha}$ or

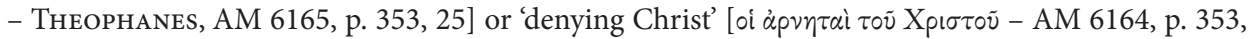
$14-15]$.

28 Theophanes concluded the description of both sieges of Constantinople with a reference to a sea storm sent by God, which destroyed Arabic fleet - Theophanes, AM 6165, p. 354, 8-11 and AM 6210, p. 399, 7-19. 
in universal categories, as a war of the entire Muslim world against Christianity, which was understood as a unity. This conjecture finds corroboration in one of the passages describing the first Arab siege of Constantinople (674-678), where the chronographer wrote that the enemy made war on sea against the Christians ${ }^{29}$. The hypothesis is also corroborated by the data including the description of the second Arab siege of Constantinople (717-718), where he mentioned that the Christians from the Arabic fleet sought refuge in the City and acclaimed the emperor ${ }^{30}$. Another interesting fact is that Leo III, so misjudged by Theophanes, was referred to as pious in the description of the siege ${ }^{31}$.

The chronographer's approach to Arab victories and the way in which he was trying to explain them, are interesting. Of course, it applies to big victories and not raids, which were numerous and mentioned regularly but only in a few words ${ }^{32}$. It should be stressed that Theophanes managed to prove that almost every Arab victory of any importance was beneficial for the Byzantines. The chronicler had a wide range of such excuses at his disposal. The first and the obvious was emphasizing the fact that the number of Arab armies outweighed the Byzantine ones. It did not matter whether this fragment was related to the primary stage of the Muslim invasion ${ }^{33}$ or the later stages of the fully constituted caliphate ${ }^{34}$.

Another excuse was bad weather conditions. Theophanes (perhaps following his source material) pointed them out particularly in his description of the first Byzantine failures, as early as in Syria. In Chronography one can find the following comment on the battle of Yarmuk: And as a south wind was blowing in the direction of the Romans, they could not face the enemy on account of the dust and were defeated ${ }^{35}$. It is hard to say whether the wind was in reality a decisive factor in this battle $e^{36}$. However, the fact that Theophanes stressed this detail is worth noticing ${ }^{37}$.

\footnotetext{
29 Theophanes, AM 6165, p. 354, 4-5.

30 Theophanes, AM 6209, p. 397, 5-8.

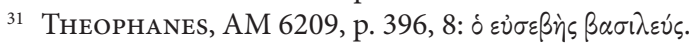

32 Theophanes reports similar raids almost every year. On the basis of these accounts we cannot state how intense they were. The frequency of such actions should not be doubted, bearing in mind Arabic tactics, which are typified by annual attacks carried out in spring and summer.

33 Theophanes, AM 6126, p. 337, 23-24.

34 Theophanes, AM 6189, p. 370, 14-15. This account covers battles in North Africa. It is essential, because according to what the Chronography says, the Byzantines outnumbered their enemies and they started to achieve victories. Nevertheless, the caliph sent an even larger fleet against them, which points to some sort of fatalism. The message that is conveyed by this passage is more or less the following - even if the empire is winning, eventually it is going to lose as the caliph will always be able to send another supplementary army.

35 Theophanes, AM 6126, p. 338, 6-7.

${ }^{36}$ A detailed analysis of the battle can be found in: W.E. KAEGI, Byzantium and the Early Islamic Conquests, Cambridge 1992, p. 112-146; D. Nicolle, Yarmuk AD 636. The Muslim Conquest of Syria, Oxford 1994, p. 65-85; W.E. KAEgI, Heraclius: Emperor of Byzantium, Cambridge 2003, p. 229-264; A.I. Akram, Yarmuk, [in:] IDEm, The Sword of Allah. Kalid bin al-Waleed, p. 1-17, http://www.grandestrategy.com/2007/12/sword-of-allah-chapter-35-yarmuk.html.

37 Especially as it has no equivalent passage in Agapius, Michael the Syrian or Chronicle of 1234, cf. R.G. HoYLAND, op. cit., p. 100-103. 
In other passages in which the chronographer describes the defeats of the Romaioi, he speaks of their inappropriate military training ${ }^{38}$ or even the rebellion as the main reason of the defeat ${ }^{39}$. a special example is a situation when the Byzantines provoked a defeat through their misemploying magical practices ${ }^{40}$. It should be highlighted that Theophanes never admitted that the Arabs were simply better warriors or sailors and that was the reason for their triumphs ${ }^{41}$.

The author of the Chronography stressed also another Arab feature - their being two-faced and their tendency to use a stratagem to reach their goals. This motif is very often present in his writing. It appears, for example, in the account concerning annus mundi 6184 (692/693 AD), during the reign of Justinian II, which covered the Muslim victory in the battle of Sebastopolis in 692. According to Theophanes, it was won only due to the fact that the Slavs, who initially fought in the Byzantine army, were enticed by the Arabs to change sides at the crucial moment in the battle. This feat is said to have been accomplished by Marwan. It seems that a double betrayal on the Muslim part took place. Firstly, the bribery of the Slavs was itself such an act towards the Byzantines. Allah's believers did not win in an honest fight but used dishonourable deception. Nonetheless, as Theophanes pointed out, the Slavic commander was also deceived, since the Arabs had made a lot of promises which they did not mean to keep ${ }^{42}$. Unfortunately, the chronographer remains silent about the nature of these promises. He passes another comment regarding the conflict in question. In the same fragment of his work he says that the Arabs feigned to be unwilling to break the peace ${ }^{43}$. If one associates it with bravura and pride attributed to Justinian $\mathrm{II}^{44}$, one can infer that Theophanes wanted to create an impression

\footnotetext{
38 Theophanes, AM 6201, p. 377, 2-5. Theophanes highlighted that a large percentage of the army, which finally lost, was based on the mass levy.

39 This reason was given by Theophanes several times, e.g. while relating the situation in 714-715 A.D. when a coup d'état made it impossible to counter the Arabic fleet effectively - THEOPHANES, AM 6207, p. 385, 5-24.

40 Theophanes, AM 6208, p. 390, 26-391, 2. On subject of the events in Pergamon, cf. W. Brandes, Apokalyptisches in Pergamon, Bsl 48, 1987, p. 1-11; M. G. VARvounis, Une pratique de magie Byzantine et la prise de Pergame par les Arabes, B 68, 1998, p. 148-156.

${ }^{41}$ This operation is also undertaken against the other tribes (countries) who the Byzantines fought with. a good example is Theophanes's description of the battle of Markellai in 792. Theophanes stressed Constantine VI's military mistakes which led to the army's failure. More on this subject vide M.J. Leszka, Wizerunek władców pierwszego państwa bułgarskiego w bizantyńskich źródłach pisanych (VIII - pierwsza połowa XII wieku), Łódź 2003, p. 31-32. a similar technique is typical as far as the other Byzantine historians are concerned, e.g. John Skyliztes - J. BONAREK, Romajowie i obcy w kronice Jana Skylitzesa. Identyfikacja etniczna Bizantyńczyków i ich stosunek do obcych w świetle kroniki Jana Skylitzesa, Toruń 2003, p. 129-131.

42 Theophanes, AM 6184, p. 366, 16-20.

43 Theophanes, AM 6184, p. 366, 6-7.

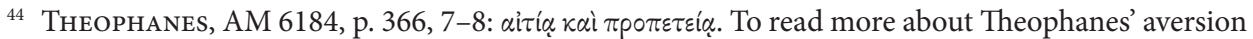
to Justinian II and about this emperor's undertakings which, according to the chronographer, resulted in his conflict with the caliph, see A. KomPA, Polityka wewnętrzna Justyniana II w świetle „Krótkiej
} 
that the Muslims provoked the emperor deliberately to make him launch a war. They were pictured in the same vein in the description of Maslama's expedition to Constantinople, more precisely of the siege of Amorium. It was there that the Arabs proclaimed Leo the emperor ${ }^{45}$. Even if the elevation did not occur, by mentioning it Theophanes reached a double goal: depreciating Leo and showing the Muslim ploy.

The Byzantine chronographer not only blamed the Arabs for using such dishonest stratagems but he also reproached them for something much worse - breaking agreements. This is also related in the description of the conquest of Tyana. According to Theophanes, the Arabs promised the town citizens inviolability. An agreement with the representatives of the city might have been reached, which was patterned after the earlier ones with Syrians and Palestinians. However, when the defenders left the fortress, they were treated contrary to what had been agreed earlier ${ }^{46}$. It seems that Maslama behaved in the same way during the siege of Charsaion ${ }^{47}$. Yet, the author of the Chronography put it concisely saying that the building was acquired through trickery.

It should be added that although the Arabs were so cunning in Theophanes' opinion, the Byzantines sometimes managed to outsmart them. Such a situation happened e.g. in the period preceding the second siege of Constantinople. The chronographer mentioned a diplomatic mission under the leadership of Daniel Sinopites $^{48}$. It was sent to Damascus under the pretence of peace talks. Nevertheless, its real aim was to spy. It ended in a total success. The Byzantines outsmarted the Muslims. In a later part of his account Theophanes presented in detail the actions of Leo, strategos of Anatolikon and the future emperor. These would also prove Arabic gullibility ${ }^{49}$.

Theophanes also emphasized Muslim cowardliness. He mentioned this e.g. in his description of Mardaites movement. Theophanes said:

In this year the Mardaites entered the Lebanon range and made themselves masters from the Black Mountain as far as the Holy City and captured the peaks of Lebanon. Many slaves, captives, and natives took refuge with them, so that in a short time they grew to many thousands. When Mauias and his advisers had learnt of this, they were much afraid, realizing that the Roman Empire was guarded by God..$^{50}$

historii” patriarchy Nicefora i „Chronografii” Teofanesa Wyznawcy, [in:] Cesarstwo Bizantyńskie. Dzieje - religia - kultura. Studia ofiarowane Profesorowi Waldemarowi Ceranowi przez uczniów na 70-lecie Jego urodzin, red. P. KRupCZyŃsKi, M.J. LeszKa, Łask-Łódź 2006, p. 113-138.

45 Theophanes, AM 6208, p. 387, 6-9.

46 Theophanes, AM 6201, p. 377, 10-14.

47 Theophanes, AM 6222, p. 409, 24-25.

48 Theophanes, AM 6206, p. 383, 31 - 384, 4. Daniel came from Sinope in Helenopontus. He was a patrician and hold the position of an eparch of Constantinople: Daniel 1, [in:] Prosopography of the Byzantine Empire, vol. I, 641-867, ed. J.R. Martindale, CD-ROM Publication, Ashgate 2001.

49 Theophanes, AM 6208, p. 386, 25 - 390, 19.

50 Theophanes, AM 6169, p. 355, 10-12. 
The Muslim reacted along the same line to the Byzantine attack of northern Syria recounted later. The chronographer highlighted here the fact the imperial forces were instilling great fear in Arabs ${ }^{51}$. The reader learns about a whole series of such passages depicting the Arabs' fear in the fragments covering Khazar-Arab warring relations ${ }^{52}$. These passages relate the years between 728 and 732. Every next Arab expedition against the Khazar territories was commented by Theophanes with a statement that the Muslims returned in a great horror ${ }^{53}$. Perhaps the chronographer just wanted to highlight the righteousness of the ByzantineTurkic alliance as the descriptions stopped after mentioning the engagement between Constantine, Leo III's son, and the Khazar princess ${ }^{54}$.

The author of the Chronography also stressed the conquerors' pride, e.g. in his account of peace talks in Egypt. According to him, the Muslims were to state that just like it was impossible for the Alexandrian patriarch to swallow a great column, it was likewise out of the question for them to leave the Egyptian territory $y^{55}$.

It should be admitted that it is very difficult to find any positive opinions on the Arabs in the analyzed source, unless calling the Muslims barbarians just once can be seen as such ${ }^{56}$. Despite appearances, it is an extremely important observation. It means that the Byzantine did not treat Islam believers in the same way as the tribes entering the northern regions of the empire. Of course one argument that can be used to contradict this view is the account of the siege of Jerusalem and the meeting between Umar I and Sophronius, the patriarch, in $637^{57}$. It seems, however, that this description should be analysed from a religious perspective. Entering a Christian temple by an infidel was evil in itself for the Byzantine author. However, Theophanes emphasizes that diplomatic missions were received with the highest honours ${ }^{58}$. He does not put it precisely what these were. Perhaps in Umayyad times a kind of diplomatic protocol existed and the Byzantines and the Muslims obeyed it in their relations ${ }^{59}$.

51 Theophanes, AM 6192, p. 371, 27-30.

52 Theophanes, AM 6220, p. 407, 5-9; AM 6223, p. 409, 27-28.

${ }_{53}$ This element is absent from the parallel relations of Agapius and Michael the Syrian; only in Chronicle of 1234 one reads Maslama was afraid and by trickery and guile he got out of their country - R.G. Hoyland, op. cit., p. 228-229.

54 Theophanes, AM 6224, p. 409, 30-31.

55 Theophanes, AM 6126, p. 338, 30-339, 4. Cf. R.G. Hoyland, op. cit., p. 109-114.

56 Theophanes, AM 6159, p. 351, 1-2.

57 Theophanes, AM 6127, p. 339, 18-24.

58 Theophanes discusses this issue in two passages: AM 6169, p. 355, 19-21.

59 A letter by Nicholas Mysticus, the patriarch, to the caliph Al-Muqtadir from the first half of $10^{\text {th }} \mathrm{c}$. is an interesting example showing how the Romaioi perceived the meaning and role of the caliphate. In this message the Byzantine Church official claims that the empire and the caliphate, being the only and, which is extremely important, equal superstates on Earth should collaborate to attain mutual advantages and universal peace, cf. G. PRINZING, Bizantyńczycy wobec obcych, trans. K. ILSKI, Poznań 1998, p. 21-23. 


\section{Caliphs}

Only a few Umayyad caliphs will be analyzed in this article, as the Chronography includes only short descriptions of the majority of the members of the dynasty. Theophanes's account is often limited to mentioning the dates of a given caliph's rule. He much more often tackled the topic of the Arabs as a group or groups than individuals comprising one society. However, there are exceptions to this rule.

Muawiya. It seems natural that the chronographer paid most attention to Muawiya. It is not surprising taking into consideration that he was the ancestor of the dynasty that had been reigning in the caliphate for 90 years ${ }^{60}$. It is worth noticing that, from Theophanes' chronological perspective, it was the longest reign in the history of the Arab empire. It appears that the chronographer appreciates the significance of this ruler. The way of gaining power from Ali made the biggest impression on him. As the Chronographer puts it: Mauias did not wish to give battle and obtained victory without any toil ${ }^{61}$. He outwitted Ali - his army separated the enemies from their stock of water. Thanks to it, the warriors started to abandon the last of the Rightly Guided Caliphs. Theophanes frequently highlights Muawiya's cunning. One example of this is an attempt of using the bishop in order to conquer a city on the island of $\operatorname{Arados}^{62}$.

According to Theophanes, the caliph was jealous of his authority. It is confirmed by a description of the rebellion of general Saborius. When the latter bowed to Andrew, a Byzantine emperor's envoy, during the audience with a Muslim ruler,

\footnotetext{
${ }^{60}$ The role that Muawiya played in asserting the Arabic reign in the conquered areas cannot be underestimated. The contribution of this ruler to establishing the foundations of the Muslim state is difficult to present in a few words. One may draw the conclusion that he adjusted the newly created state to the administrative and fiscal standards which were the norm in these times. It seems indisputable that he acted in accordance with to previously tested out strategies, both Byzantine and Persian. $\mathrm{He}$ did not mind if they were not in total agreement with Islamic rules (teaching). a good example here is his using maqșurry, a bower separated from the mosque, where the caliph could spend his time without the rest of ummah. This behavior shows the desire for sacralization of the ruler. It should be pointed out that according to Arabic tradition the son of Abu Sufyan is included into the so-called duhat, which in free translation means geniuses, who created the power of the caliphs' empire. $\mathrm{He}$ was also believed to have a feature, typical for outstanding people only, which is hilm - sensibility, wisdom, empathy, gentleness and understanding; the features of the true ruler. More on the subject of this ruler's reign cf. J.J. SAUndERs, A History of Medieval Islam, London 1965, p. 59-70; P. HitTi, History of the Arabs, London 1937, p. 161-171; G.R. Hawting, The First Dynasty of Islam. The Umayyad Caliphate AD 661-750, Carbondale-Edwardsville 1987, p. 24-45; D. MADEYska, Historia świata arabskiego. Okres klasyczny od starożytności do końca epoki Umajjadów (750), Warszawa 1999, p. 155-170; H. KenNedy, The Prophet and the Age of the Caliphates. The Islamic Near East from the Sixth to the Eleventh Century, London-New York 2004, p. 82-90.

${ }_{61}$ Theophanes, AM 6148, p. 347, 3-4. Compare the different approach of Agapius, Michael the Syrian and Chronicle of 1234 - R.G. HoyLAND, op. cit., p. 147.

62 Theophanes, AM 6140, p. 343, 30 - 344, 10.
} 
he was severely reprimanded by Muawiya. The son of Abu Sufyan was to say: You will no longer do obeisance to Andrew, since by so doing you will achieve nothing ${ }^{63}$.

The majority of references to Muawiya amount to mentioning the caliph's war expeditions. It suggests that the Byzantine perceived the founder of the Umayyad dynasty mainly as a commander and a conqueror.

Walid I. In two instances Theophanes commented on the caliph's actions in only one or two sentences. He calls Walid I wretched ${ }^{64}$. It should not be taken literally. The Byzantine writer uses this epithet to refer to a person who is unhappy because of persecuting the Christians. This word does not have an earthly dimension but a spiritual one. It seems that because of the persecution, Yazid II is called thoughtless by Theophanes. It is probably connected with his alleged affection for the Jews ${ }^{65}$.

Umar II. The description of Umar II's actions is much more detailed. It should be stressed that the author of the Chronography greatly contributed to the creation of a complicated legend of this caliph ${ }^{66}$, which, in fact, survived till today ${ }^{67}$. First of all the chronographer summarized in one account regarding his reign all the information on the anti-Christian Umayyad regulations that he covered in his work. The first one was expressed in the following words: Oumar banned the use of wine in cities ${ }^{68}$.

${ }_{63}$ Theophanes, AM 6159, p. 349, 18-19. Cf. the versions of the parallel sources - R.G. Hoyland, op. cit., p. 156-161.

${ }_{64}$ Theophanes, AM 6199, p. 376. The word $2 \lambda$ ı $\tau$ ' Cf. R.G. Hoyland, op. cit., p. 199-200 for parallel readings from the Syriac chronicles, yet without the epithet.

65 Theophanes, AM 6215, p. 402, 3-4. On the other hand the expression used by Theophanes could be aimed to imply that Yazid was only a thoughtless or weak-willed tool, in the hands of the Jews. It should be added that Yazid II was not really respected also among Christian writers staying in the areas of Muslim occupation, cf. История халифов вардапета Гевонда, писательа VIII века, trans. К. Патканиян, Санкт-Петербург 1862 (cetera: GHevond), p. 70-71 and Severus AL-Ashmunein, History of the Patriarchs of the Coptic Church of Alexandria [part 3: Agathon - Michael I (766 A.D.)], trans. B. EvetTs, Paris 1910 (cetera: HPA), p. 72-73.

66 A. Borrut, Entre tradition et histoire: genèse et diffusion de l'image de 'Umar II, MUSJ 58, 2005, p. 329-278.

${ }^{67}$ The figure of Umar Ibn 'Abd al-Aziz generates considerable controversy in the literature on the subject. There are references to his anti-Christian policy (D. MADEYskA, op. cit., p. 182). However, at the same time some authors emphasize his huge tax discounts for Muslim neophytes of non-Arabic origins (P.K. HiтTI, op. cit., p. 186). In the later Abbasid period, Umar II was perceived in a totally different way than the rest of Umayyad caliphs. It is worth mentioning that his tomb was not despoiled unlike other Umayyad rulers' tombs (ibidem, p. 189). His piety was looked upon with such respect that one of the caliphs, Al-Mukhtadi, chose him as his ideal of a perfect ruler - J. HauzIŃski, Burzliwe dzieje kalifatu bagdadzkiego, Warszawa-Kraków 1993, p. 174. We should agree with Gerald Hawting (op. cit., p. 77), who wrote that the accounts by Arabic chroniclers which are all utterly positive, often make it difficult to create an objective description of his reign.

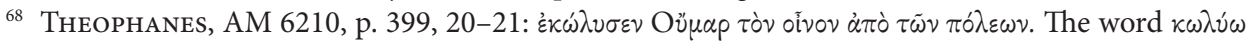
with $\dot{\alpha} \pi o^{\prime}+a c c$. means 'deny somebody something. Thus, in literal translation this fragment should be read as: 'Umar denied the cities their wine'. 
Comparing this passage with available versions of the Pact of Umar ${ }^{69}$, one can come to the conclusion that the ban referred to selling and buying wine in the cities described as Muslim ${ }^{70}$. However, using wine itself by the Christians was not forbidden.

The second regulation included in this fragment is the one which says that a Christian's testimony against a Muslim will not be accepted ${ }^{71}$. By mentioning it, Theophanes asserts another ban included in the Pact, which states that: you will not allow him to marry in the presence of your witnesses, nor to partake in a marriage we consider illegal ${ }^{72}$.

Apart from listing these regulations, the chronographer also mentions the fact that Muslim neophytes were exempt from $\operatorname{tax}^{73}$. Theophanes considers this law to be another repression of the Christians ${ }^{74}$. It is understandable as the rescript notably improved the situation of mawali. a lot of people encouraged in this way committed apostasy and converted to Islam ${ }^{75}$. The account of Umar II's actions is concluded with a reference to a letter written by Umar II to Leo III $^{76}$. The caliph hoped to convert the Romans to Islam ${ }^{77}$.

It appears that Theophanes presents Umar II as a fanatic Islam believer, who went so far as to try to convert the emperor, who was a zealous persecutor of the Christians. It should be noticed that many eastern sources do not show the Umayyad ruler in such negative light ${ }^{78}$.

${ }^{69}$ Cf. R.G. Hoyland, op. cit., p. 215-217. This document has been tackled by a few writers before. At first, it was thought to have been written by Umar I, later by Umar Ibn 'Abd al-Aziz. At present it is considered to have been created in a form of a coherent document much later: K. KościelniaK, Grecy i Arabowie. Historia Kościoła melkickiego (katolickiego) na ziemiach zdobytych przez muzułmanów (634-1516), Kraków 2004, p. 76-80.

70 This ban referred also to blood, carrion and swines - Classical Islam. a Sourcebook of Religions Literature, trans. N. CAlder, J. Mojaddedi, A. RipPin, Abingdon-New York 2003, p. 91-92.

71 Theophanes, AM 6210, p. 399, 24-25.

72 Classical Islam..., p. 91.

73 Theophanes, AM 6210, p. 399, 20-22.

${ }^{74}$ Coptic HPA (p. 72) presents the function of this rescript by Umar in a similar fashion.

75 H.A.R. GibB, The fiscal rescript of 'Umar II, Ara 2, 1955, p. 1-16; P.K. HitTi, op. cit., p. 186.

76 Theophanes, AM 6210, p. 399, 25-26.

77 The authenticity of the letter, a rewritten version of which is included in the History of the Caliphs by Ghevond, is sometimes doubted. However, the fact of the existence of such correspondence seems probable. Perhaps the original letter has not lasted until our times and only a fake version survived. More on this subject: K. KościelniaK, Polemika muzułmańsko-chrześcijańska na podstawie korespondencji przypisywanej kalifowi umajjadzkiemu 'Umarowi II († 720) i cesarzowi bizantyjskiemu Leonowi III ( † 741), FHC 8, 2002, p. 97-105.

${ }^{78}$ The author means here the following sources: GHevond, p. 29 and 70; HPA, p. 71-72. More: B. CEСотA, 'Umar II - przyczynek do nowego spojrzenia na postać umajjadzkiego kalifa (in press). 
Hisham was another caliph characterised by Theophanes ${ }^{79}$. The writer does not present a detailed description of this ruler ${ }^{80}$. On the one hand, he portraits him as a friend of Stephen IV, the future patriarch of Antioch. He notes that the caliph contributed to his elevation to the patriarchal throne. On the other hand, he blamed Hisham for persecuting and ordering to murder the Byzantine captives ${ }^{81}$.

As Theophanes puts it, the caliph was a great builder: his brother Isam became caliph and started to build palaces in the country and in towns, to lay out plantations and gardens and to channel water ${ }^{82}$. Nonetheless, the chronographer does not appreciate the caliph's military skills. In the same fragment he says: he campaigned against the Roman country and, after losing many of his men, returned home ${ }^{83}$.

Marwan II was the last ruler depicted by the chronographer and covered in more depth ${ }^{84}$. It seems that the description of the struggle to maintain the dynasty,

79 During the reign of this caliph the Umayyad power was reborn. It was mainly reflected by the military activity. They managed to defeat the Khazars in 737 and take control of Turgesh in the east. However, military expeditions were costly, and rising taxes led to the feeling of dissatisfaction among the people. The last years of Hisham's rule were dominated by fighting rebellions, among others the uprising of the Berbers. The domestic policy of Hisham boiled down to keeping balance between Qays and Yemen. In the short view such a policy was successful as it ensured peace. Nevertheless, it resulted in a civil war and, consequently, the fall of the dynasty. More on the subject of Hisham, cf. K.Y. Blankinship, The End of the Jihäd State. The Reign of Hishām Ibn 'Aba Al-Malik and the Collapse of the Umayyads, Albany 1994, passim; G.R. HaWting, op. cit., p. 81-88; D. MADEYsKA, op. cit., p. 183-186; H. KeNNEDY, op. cit., p. 108-112.

${ }^{80}$ It is presented in literature in different ways, e.g. Dariusz Górski describes his reign as a period of financial oppression, also of Christians, whereas Krzysztof Kościelniak highlights his tolerance towards people of different faith, cf. D. GóRsKI, Sytuacja chrześcijaństwa na terenach Pótnocnej Afryki od podbojów muzułmańskich do XII wieku, Kraków 2004, p. 80; K. KoścIelniaK, Historia Kościoła melkickiego..., p. 72-73.

81 Theophanes, AM 6232, p. 414, 3-9. This account is related to the martyrdom of Byzantine captives (e.g. Eustathius), who were captured during the raid of Sulaiman, the son of Hisham - TheoPHANES, AM 6230, p. 411, 10-12. More on this subject cf. B. СесотA, „Klatwa na Mahometa i jego opowieści, i wszystkich, którzy wierza w nie!" - prześladowania chrześcijan przez Umajjadów w Syrii na podstawie „Chronografii” Teofanesa Wyznawcy, PNH 8.1, 2009, p. 143-152.

82 Theophanes, AM 6216, p. 403, 24-27.

83 Theophanes, AM 6216, p. 403, 27-28. To compare here with similar passages in Agapius, see R.G. Hoyland, op. cit., p. 221-222.

${ }^{84}$ Despite his efforts, Marwan did not manage to save the dynasty from the fall. It should be added, however, that to the same degree he was also responsible for it. Never before had the Umayyad been so divided as during his reign. Additionally, Marwan was supported by the Qays, who had been underestimated so far. The Yemens rebelled as early as at the beginning of his reign, however their rebellion was quelled. Had it not been for the inner disagreements, Umayyad could have succeeded in keeping the throne. The uprising of the Abbasid was obviously not the first one in Persia. From today's point of view, the alliance that Sulaiman Ibn Hisham made with the rebels may seem strange. However, the pretender aimed to use the rebellion to gain the throne. He probably did not envisage such tragic consequences, especially that the Persian areas remained on the sidelines and were not given much attention. The center of the caliphate consisted of Syria and Egypt, and thus, these were the regions of the activity of Marwan's armies. More on this subject: É.-C. AMÉLINEAU, Les derniers jours et le mort du khalife 
included in the Chronography, is quite adequate. As Theophanes points out several times in his work, Marwan II was responsible for the carnage of either the citizens of the towns he had conquered or of his political opponents ${ }^{85}$. It is obvious that the chronographer knew such acts to be the main reason for the caliph's failure and judged the times of his reign through the extent of destruction caused by his armies in Syria. He states (the passage has no equivalent in the Syriac sources ${ }^{86}$ ): the devastation in the days of Marouam lasted six years and in the course of it all the prominent cities of Syria lost their walls except Antioch, which he planned to use as a refuge ${ }^{87}$. Marwan was presented as a ruler not only neglecting his country but also responsible for its collapse. Additionally, Theophanes blames the caliph for supporting heretics and pagan practises ${ }^{88}$. The fact that a Christian recognized sinfulness in violating Islamic rules is extremely interesting. Theophanes also refers to moving the capital to Har$\operatorname{ran}^{89}$, which was one of the main mistakes of the son of Muhammad Ibn Marwan.

At the same time he stresses that it was Marwan II who provided protection and showed reverence for Theophylact, the patriarch of Antioch ${ }^{90}$. Equally, Theophanes' attitude towards the way of seizing power by the caliph seems to be ambiguous. It is true that he emphasized that Marwan II only wanted ostensibly to support Oualid's sons and oppose Izid ${ }^{91}$, however later he also said that he had waged this war on behalf of dead Walid.

The chronographer appreciated Marwan's courage and persistence, highlighting the fact that the last Umayyad caliph did not surrender until the end. As he puts it: in this year Marouam was pursued by the Maurophoroi, who captured him and killed him after waging a very heavy war ${ }^{92}$.

The chronographer also added in one of the later accounts that a few rebellions that broke out in Syria ended on the arrival of Marouam's embalmed head ${ }^{93}$. Theophanes made a remark about the fact that not everyone was in accord with the change of the dynasty, which is also proved by Abbasid actions ${ }^{94}$. The chronogra-

Merouân II d'aprés l'Histoire des patriarches d'Alexandrie, JA 4, 1914, p. 421-449; P. Hiтt, op. cit., p. 230-236; G.R. HAwTing, op. cit., p. 96-119; D. MadeysKa, op. cit., p. 200-209; H. KenNedy, op. cit., p. 112-122.

${ }^{85}$ We can distinguish here three accounts of this type. The first one refers to the revenge of Marwan on the killers of Walid II cf. Theophanes, AM 6235, p. 419, 2-5. The next tells the story of the fate of two rebels Tabit Ibn Nu 'aim and Dahhak Ibn Qays, AM 6236, p. 421, 17-20. The last refers to the defeat of Emesa: AM 6237, p. 422, 19-23.

86 R.G. Hoyland, op. cit., p. 280-283, 311.

87 Theophanes, AM 6241, p. 426, 7-9.

88 Theophanes, AM 6241, p. 426, 11-13.

89 Theophanes, AM 6235, p. 419, 5-6.

90 Theophanes, AM 6236, p. 421, 20-24.

91 Theophanes, AM 6235, p. 418, 21-22.

92 Theophanes, AM 6241, p. 425, 13-15.

93 Theophanes, AM 6242, p. 427, 6-7.

94 The Umayyad dynasty was held in high esteem among the Muslims long after 750, especially in Syria - J.A. Bellamy, Pro-Umayyad Propaganda in Ninth-Century Baghdad in the Works of Ibn Abīl-Dunyā, 
pher does not seem completely neutral when reporting this conflict. According to him, Abbasid started their reign with political and religious persecutions ${ }^{95}$.

In conclusion, it should be accentuated that the Chronography still proves a very valuable source, useful also in researching the Byzantine approach to Islam. The fact that Theophanes was a member of the social elite and yet he took part in monastic life may suggest that his work presents the views acceptable for both significant groups comprising the empire. Theophanes possessed detailed knowledge of the Arabs, Islam and Umayyads themselves. He used, although presumably indirectly, some Muslim sources in his work. The argument which strongly proves this hypothesis is his precise description of inner clashes between the members of the ruling house, as well as of Arab civil wars.

Translated by Konrad Figat

\begin{abstract}
As the Chronography of Theophanes the Confessor includes a lot of information about the foreign states and tribes which were connected with the Byzantine Empire. It is legitimate, in the Author's view, to analyse the account concerning Islam and the Arabs by this Byzantine author. Theophanes possessed detailed knowledge of the Arabs, Islam and Umayyad caliphs. He used, although presumably indirectly, some Muslim sources in his work. The argument which strongly proves this hypothesis is his precise description of inner clashes between the members of the ruling house, as well as of Arab civil wars. The article discusses how Theophanes (and presumably his sources) depicted not only the Arabs as an entity, but also the prophet Muhammad and some of the Umayyad caliphs (Muawiya, Walid I, Umar II, Hisham, Marwan II).
\end{abstract}

\author{
Błażej Cecota \\ Katedra Historii Bizancjum \\ Wydział Filozoficzno-Historyczny \\ Uniwersytet Łódzki \\ ul. A. Kamińskiego 27a \\ 90-219 Łódź, Polska \\ blazejcecota@wp.pl
}

[in:] Prédication et propagande au Moyen Age. Islam, Byzance, Occident. Session des 20-25 octobre 1980, ed. G. Makdisi, D. Sourdel, J. Sourdel-Thomine Paris 1983, p. 71-86. The ruler of this country, As-Salih, brother of al-Mansur, married Marwan II's widow to create the appearances of succession, cf. H. Kennedy, The Court of the Caliphs. The Rise and Fall of Islam's Greatest Dynasty, London 2004, p. 53. 95 Theophanes mentions the Abbasid repression of Christians a few times. The reason for them was mainly politics. In the relation from AM 6243, the Byzantine recalls a murder of a group of Christians (p. 427, 12-14). Theophanes clearly suggests the relationship between Christians and Umayyads. The exile of Theodor, the patriarch of Antioch by Salih Ibn Ali could be linked with politics, cf. AM 6248, p. 430, 2-7. 